\title{
会 告
}

会員各位

\section{2 年度会費納入のご案内}

平素より本会の学会活動をご支援賜り心より御礼申し上げます.

勤務先や住所等の変更がある場合は, 次頁の「会員登録事項変更届」を必ず提出してください. 2021 年度をもって退会される場合は，2021 年度までの会費を完納の上で 2022 年 3 月 23 日（必 着）までに退会届を提出してください. 退会の連絡がない場合は会員を継続されるものとします. 次年度（2022 年 4 月 1 日〜2023 年 3 月 31 日）会費納入につきましてご案内申し上げます.

\section{[支払い方法］}

\section{口振込用紙による支払い}

次年度になりましたら 2022 年度会費の振込用紙を郵送いたします。

口自動口座振替（銀行（ゆうちょ銀行含む）・信用金庫・信用組合など）

既に申込みをされている場合, 新たな手続きは不要です. 新規申込みの場合は, 本会ホームペー ジ（トップページ左下の「会費の口座振替」）より申込書をダウンロードして必要事項を記入の 上，事務局へ郵送してください（これからの申込みは 2023 年度年会費からの適用になりますの でご了承ください).なお, 振替日は毎年 4 月 27 日（金融機関休業日の場合，翌営業日）です.

\section{銀行口座振込}

会費（正会員 12,000 円，代議員 18,000 円）を次の口座までお振込みください.

\section{みずほ銀行 本郷支店（075）}

口座番号：普通 1905688

口座名：シヤ）二ホンロウネンイガクカイ

*振込みの際は, 氏名の前に会員番号を付けてください.

*手数料はご負担ください

一般社団法人日本老年医学会 事務局

干113-0034 東京都文京区湯島 4-2-1 杏林ビル 702 FAX : 03-3814-8604

E-mail : rounen@jpn-geriat-soc.or.jp 


\section{会員登録事項変更届}

下記の通り連絡します

年月日

該当する項目を○で囲んでください

1 . 自宅住所変更

2. 勤務先変更

3. 学会誌送付先変更

4. 退会 ※会費完納の上ご提出ください

5. その他

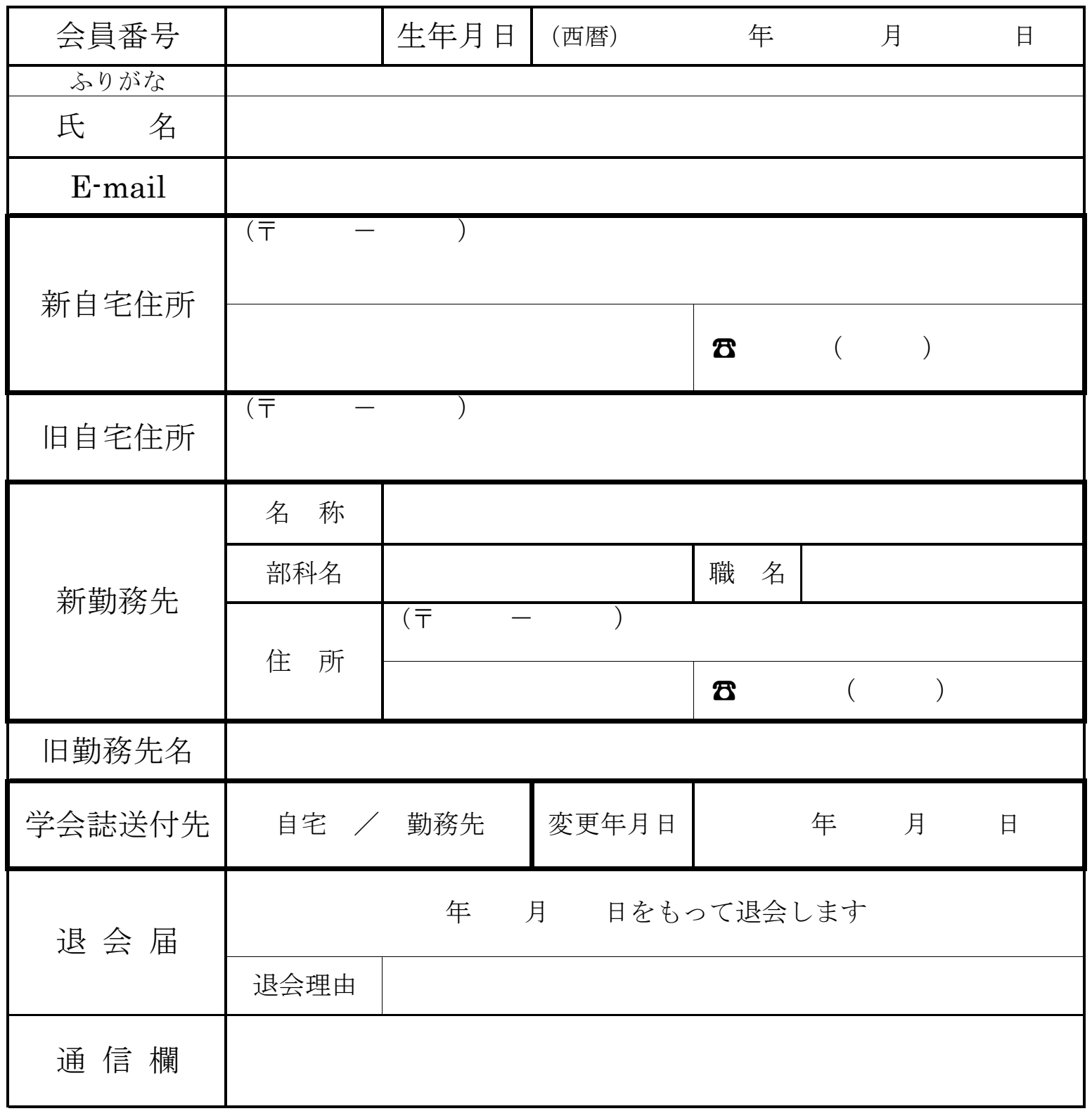

一般社団法人日本老年医学会 事務局

̄113-0034 東京都文京区湯島4-2-1 杏林ビル702

TEL : 03-3814-8104 / FAX : 03-3814-8604

E-mail : jgs@blue.ocn.ne.jp 


\section{2 年度日本老年医学会学術集会開催のご案内}

\section{会員各位}

時下，会員の皆様におかれましては益々ご健勝のこととお慶び申しあげます.

2022 年度第 64 回日本老年医学会学術集会は下記の通り開催を予定しております.

一般演題へのご応募および，本大会への多数のご参加を心よりお待ち申しあげます.

第 64 回日本老年医学会学術集会

会長 楽木 宏実

事務局長 山本 浩一

\footnotetext{
会 期 : 2022 年 6 月 2 日 (木) 4 日（土）

会 場 : 大阪国際会議場

テ 一 マ：幸福長寿実現のための老年医学：知と技の結集
}

http://www.congre.co.jp/64jgs/index.html

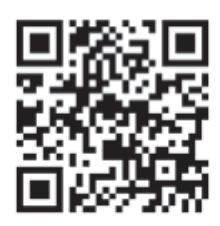

(第 64 回大会 HP)

\section{主要プログラム :}

ロ海外招請講演（オンライン）

• 演者 : Professor Athanase Benetos, MD, PhD (President of the European Geriatric Medicine Society (EuGMS), Head of the Geriatric Department, University Hospital of Nancy, Director of the FHU-CARTAGE, Université de Lorraine)

テーマ: Treatment strategies in old hypertensive subjects according to their functional status

\section{特別講演}

·演者 : 熊ノ郷 淳 (大阪大学大学院医学系研究科呼吸器・免疫内科学)

·演者 : 岩坪威 (東京大学大学院医学系研究科神経病理学)

·演者：柇原 哲也（東京女子大学現代教養学部人文学科哲学専攻）

口理事長講演

- 演者 : 秋下 雅弘 (東京大学大学院医学系研究科老年病学)

\section{口会長講演}

- 演者 : 楽木 宏実 (大阪大学大学院医学系研究科老年・総合内科学)

\section{口尼子賞受賞講演}

教育講演 $(20$ 講演 $)$

動画のオンデマンド配信を予定（シリーズ座長による紹介動画を配信予定） 


\section{〈老年医学研究シリーズ>}

シリーズ座長 : TBA

・細胞老化, 個体老化の基礎研究

・老化研究におけるモデル動物

・加齢と認知症研究の最前線または認知症の遺伝子解析

・早老症研究の最前線

・老年学におけるデジタルヘルスの未来（デジタルヘルス政策）

\section{〈老年科医が老年医学を究めるシリーズ 1>}

シリーズ座長：TBA

・ICOPE ガイドラインに学ぶ高齢者のための包括的ケア

・高齢者総合機能評価を日常診療にどう活かすか

・フレイル，サルコペニアの評価を日常診療に活かす

・ポリファーマシーと PIMへのアプローチ

・低栄養に対する多職種協働アプローチ

\section{く老年科医が老年医学を究めるシリーズ $2>$}

シリーズ座長：TBA

・ treatable dementia を見逃さないために/BPSD をどのように対処するか？

・高齢者の運転免許証：日常診療での対応のエッセンス

- medical aromatherapy と老年症候群

・認知症医療・ケアに役立つ評価法

\section{〈老年科医の診療レベルアップシリーズ>}

シリーズ座長 : TBA

・高齢者の感染症

・高齢者の頻尿, 膀胱疾患

・高齢者てんかん

・高齢者の皮虐疾患

·加齢性平衡障害という概念と治療

・高齢者における腎代替療法

ロシンポジウム（テーマ名は一部仮題）

\section{<老年医学推進 5 か年計画 $>$}

- 第 2 期老年医学推進 5 か年計画に向けて（1）推進状況と未来への課題 座長 : 秋下 雅弘 (東京大学大学院医学系研究科老年病学)

座長 : 神㟝 恒一 (杏林大学医学部高齢医学)

- 第 2 期老年医学推進 5 か年計画に向けて（2）老年医学会次世代による未来への挑戦 座長 : 横手幸太郎 (千葉大学大学院医学研究院 内分泌代謝 - 血液・老年内科学) 座長：飯島 勝矢（東京大学高齢社会総合研究機構/未来ビジョン研究センター） 


\section{<老年医学の未来医療 $>$}

・いのち輝く未来社会のデザインと老年医学 : 大阪万博への期待

座長 : 森下 竜一 (大阪大学大学院医学系研究科臨床遺伝子治療)

座長 : 青木 元邦 (森ノ宮医療大学)

・リジュベネーションを目指した老化研究

座長 : 茂木 正樹 (愛媛大学大学院医学系研究科 薬理学)

座長 : 新井 康通（慶應義塾大学看護医療学部/医学部百寿総合研究センター）

・胎児期環境・小児期が与える将来の老化 座長 : 茂木 正樹 (愛媛大学大学院医学系研究科 薬理学)

座長 : 吉田守美子 (徳島大学大学院医歯薬学研究部血液・内分泌代謝内科学)

・健康長寿実現のための地域社会のあり方一ゼロ次予防の視点から-

座長 : 飯島 勝矢 (東京大学高齢社会総合研究機構/未来ビジョン研究センター)

座長 : 神出計 (大阪大学大学院医学系研究科保健学専攻総合ヘルスプロモーション科学講座)

• Senior Friendly Hospital を目指して

座長：武地一（藤田医科大学医学部認知症・高齢診療科）

座長 : 梅垣 宏行 (名古屋大学大学院医学系研究科地域在宅医療老年科学)

\section{<新型コロナと老年医学 $>$}

・新型コロナ感染から見えた認知症医療/介護/共生の課題と対策

座長 : 石井 伸弥 (広島大学大学院医系科学研究科共生社会医学講座)

座長 : 粟田 主一（東京都健康長寿医療センター研究所）

・新型コロナ感染から見えた高齢者診療の課題と対策

座長 : 三浦 久幸 (国立長寿医療研究センター在宅医療・地域医療連携推進部)

座長：千田 一嘉（金城学院大学薬学部）

\section{<領域横断的医療の推進 $>$}

·領域横断的なフレイル・ロコモ対策の推進

座長：大江 隆史（NTT 東日本関東病院）

座長 : 鈴木 隆雄（桜美林大学 大学院 教授)

・老年科医が支えるチーム医療の実践に学ぶ

座長 : 大黒 正志 (金沢医科大学 高齢医学)

座長：鷹見 洋一 (大阪大学大学院医学系研究科 老年・総合内科)

・高齢者がん診療

座長 : 杉本研 (川崎医科大学 総合老年医学)

座長：山本＼cjkstart寛（東京都健康長寿医療センター呼吸器内科） 
・LIFE 実装がもたらしたものと今後の課題

座長 : 大河内二郎 (介護老人保健施設竜間之郷)

座長 : 海老原 覚 (東邦大学大学院医学研究科リハビリテーション医学講座)

- ACP の進め方

座長 : 勝谷 友宏（医療法人社団 勝谷医院）

座長 : 会田 薰子 (東京大学大学院人文社会系研究科死生学・応用倫理センター上廣講座)

\section{<在宅医療 $>$}

・高齢者オンライン診療の課題と未来

座長：野村 和至（医療法人社団野村医院）

座長 : 本間 聡起（独立行政法人 地域医療機能推進機構 埼玉メディカルセンター）

・在宅医療の役割を徹底討論

座長：山中崇 (東京大学大学院医学系研究科 在宅医療学講座)

座長：亀井 智子 (聖路加国際大学大学院看護学研究科)

\section{<認知症 $>$}

・認知症予防の社会実装を考える

座長 : 櫻井孝（国立研究開発法人 国立長寿医療研究センター）

座長 : 古和 久朋 (神戸大学大学院保健学研究科)

• MCI からの認知機能の回復について

座長：下濱俊（医療法人社団慈誠会 慈誠会記念病院）

座長 : 羽生 春夫（総合東京病院 認知症疾患研究センター）

・認知症基礎研究の最前線

座長：荒井 啓行（東北大学加齢医学研究所）

座長：里直行（国立長寿医療研究センター・認知症先進医療開発センター・分子基盤研究部）

- 認知症治療法の最前線

座長：岩田淳（東京都健康長寿医療センター）

座長 : 竹屋泰 (大阪大学大学院医学系研究科保健学専攻看護実践開発科学講座)

・ケアチームによる入院患者の認知症・せん妄対策

座長 : 吉山 顕次 (大阪大学大学院医学系研究科 精神医学教室)

座長：柳川まどか（医療法人馨仁会＼cjkstart豊田東リハビリテーション病院）

\section{くフレイル・サルコペニア＞}

・サルコペニア基礎研究の最前線

座長：佐竹 昭介（国立長寿医療研究センター 老年内科）

座長：杉本＼cjkstart研（川崎医科大学 総合老年医学） 
・フレイル, サルコペニアのバイオマーカー

座長 : 近藤 祥司 (京都大学医学部附属病院高齢者医療ユニット)

座長 : 中神 啓徳 (大阪大学大学院医学系研究科健康発達医学)

·後期高齢者健診の実践的活用法

座長 : 荒井 秀典 (国立長寿医療研究センター)

座長：津下 一代（女子栄養大学）

・住居環境整備から進めるフレイル予防と地域医療

座長：野村 和至（医療法人社団野村医院）

座長：羽鳥裕 (公益社団法人日本医師会 常任理事)

・ ウロフレイルの研究と診療の最前線

座長：藤村 哲也 (自治医科大学 腎泌尿器外科学講座)

座長：吉田 正貴（桜十字病院 泌尿器科・国立長寿医療研究センター）

\section{<転倒・骨折・骨粗鬆症＞}

・骨折転倒予防に向けた多職種協働・住民啓発の重要性

座長：小川 純人 (東京大学大学院医学系研究科老年病学)

座長 : 三浦 雅一 (北陸大学薬学部/北陸大学健康長寿総合研究グループ)

・多職種で取り組む高齢者大腿骨近位部骨折

座長 2 名: TBA

・高齢者診療において内科医が知っておくべき運動器疾患の知識と実践-2022 年アップデート

座長：酒井 昭典（産業医科大学整形外科）

座長：浦野 友彦（国際医療福祉大学医学部老年病学講座）

\section{くリハビリテーション>}

・高齢者のリハビリテーション医療

座長：上月 正博 (東北大学大学院医学系研究科内部障害学分野)

座長 : 海老原 覚 (東邦大学大学院医学研究科リハビリテーション医学講座)

\section{<高齢者の慢性疾患管理 $>$}

- 高齢者頭痛性疾患 Update

座長：竹島多賀夫（社会医療法人寿会 富永病院 脳神経内科・頭痛センター）

座長 : 吉岩あ抒い (大分大学医学部看護学科実践看護学講座老年看護学/総合診療・総合内科学)

・誤觾性肺炎の予防・治療・ケア・EOL

座長：前田 圭介（国立長寿医療研究センター 老年内科）

座長 : 若林 秀隆（東京女子医科大学病院リハビリテーション科） 
·高齢者の腎臓病治療の最前線

座長：伊藤 孝史（島根大学医学部附属病院 腎臓内科）

座長 : 猪阪 善隆 (大阪大学大学院医学系研究科腎臓内科学)

・高齢者糖尿病治療目標が策定されて 6 年の進歩

座長：荒木 厚（東京都健康長寿医療センター糖尿病・代謝・内分泌内科）

座長 : 池上 博司 (近畿大学医学部 内分泌 - 代謝 - 糖尿病内科)

・高齢者の心不全パンデミックに備える

座長 : 大石 充 (鹿児島大学 心臓血管・高血圧内科学)

座長：木田 圭亮（聖マリアンナ医科大学 薬理学)

・人生 100 年時代に目ざすべき最適な薬物療法とは?～医師・薬剤師連携によるポリファーマシー対策〜 座長 : 江頭 正人 (東京大学大学院医学系研究科 医学教育国際研究センター 医学教育学部門)

座長：恩田 光子 (大阪医科薬科大学薬学部)

・老年症候群に対する非薬物療法の現状と期待

座長 : 神嵉 恒一 (杏林大学医学部高齢医学)

座長：島田 裕之（国立研究開発法人 国立長寿医療研究センター 老年学・社会科学研究センター)

・補完代替医療と老年医学

座長 : 伊藤 壽記 (大阪がん循環器病予防センター)

座長：山下仁（森ノ宮医療大学大学院保健医療学研究科）

委員会特別企画

\section{<教育委員会 $>$}

・若手・基礎研究ミーティング

\section{〈ダイバーシティ推進委員会 $>$}

・ダイバーシティとサスティナブル老年医学「人生いつでもどこでも老年医学 (仮)」

・みんなのティーサロン

第 5 回日本老年医学会 老化および老年医学研究助成受賞者講演 (2020 年度)

- 座長 2 名 : TBA

・演者：

杉本＼cjkstart研（川崎医科大学）サルコペニアを促進する病態における運動の有効性に関するマイオカイン IL-15 の役割の解明

高山 賢一（東京都健康長寿医療センター）新たな認知症発症メカニズム解明に向けた RNA 結合蛋白質群が 担うスプライシング制御機構の基礎的研究

服部 頼都（国立循環器病研究センター）血管内皮依存性脳血流増加を基盤とした認知症の革新的治療法の開 発 
第 4 回日本老年医学会 YIA 受賞者講演

- 座長 2 名：TBA

口認知症診療の実践セミナー

座長：大内 尉義（虎の門病院）

座長：浦上 克哉 (鳥取大学)

ロランチョンセミナー・スポンサードセミナー（一部上記シンポジウムを含む）（計 25 予定）

ロ一般演題：口演・ポスター

口倫理教育講習会

口市民公開講座（第 33 回日本老年医学会近畿地方会（会長：神出計）市民公開講座と併催） 